\title{
TNFSF9 Gene Mutation Negative
}

National Cancer Institute

\section{Source}

National Cancer Institute. TNFSF9 Gene Mutation Negative. NCI Thesaurus. Code C153523.

A genetic finding indicating that TNFSF9 gene mutations have not been detected in a sample. 